\title{
SCIENTIFIC PHYSICAL CORE STRENGTH TRAINING OF ADOLESCENT GROUP
}

\author{
TREINO CIENTÍFICO DE FORÇA DO CORE DE UM GRUPO DE ADOLESCENTES
}

Original Article

ENTRENAMIENTO CIENTÍFICO DEFUERZA DEL COREDE UN GRUPO DEADOLESCENTES

ARTIGO ORIGINAL

Artículo Original

\author{
Juqian $\operatorname{Pan}^{1}$ (D) \\ (Physical Education Professional) \\ Meiliang $\mathrm{Wei}^{2}$ (DD \\ (Librarian) \\ 1. Faculty of Physical Education, \\ Hechi University, Yizhou, China. \\ 2. Library, Hechi University, Yizhou, \\ China.
}

\section{Correspondence:}

Meiliang Wei

Yizhou, China. 546300.

panzuxin2018@126.com

\begin{abstract}
Introduction: A strong core can be more stable and improve the body posture of adolescents. This enables the organic integration and development of all parts of the body, as well as the coordination of the upper and lower limbs. Core strength training is conducive to improving its physical strength in the youth group. Objective: To study the influence of core strength on adolescents' motor skills and physical literacy. Methods: 40 teenagers were selected for group training. The experimental group performed core strength training, while the control group used traditional strength training. After the training period, the improvement of the physical fitness and motor skills of the two groups of volunteers was analyzed. Results: There were statistical differences between the two groups of young athletes in various technical and physical fitness indicators. Conclusion: Core strength training can improve the basic skills of young athletes, such as fast running, jumping and so on, but the effect of improving high physical fitness is not obvious. The experiment shows that a certain period of core strength training can improve their physical and motor skills. In future training for youth, core strength training should be advocated. Level of evidence Il; Evidence from well-designed randomized controlled trials.
\end{abstract}

Keywords: Adolescent; Athletes; Physical Fitness Test; Strength Training.

\section{RESUMO}

Introdução: Um core mais forte pode ser mais estável e melhorar a postura corporal de adolescentes. Isso permite que haja uma integração orgânica e um desenvolvimento de todas as partes do corpo, assim como a coordenação dos membros superiores e inferiores. O treino da força do core leva à melhoria de sua força física no grupo de jovens. Objetivo: Estudar a influência da força do core nas habilidades motoras e na literacia física. Métodos: 40 adolescentes foram selecionados para treinamento em grupo. O grupo experimental passou por um treino da força do core, enquanto o grupo controle passou por treinos de força padrão. Depois do período de treino, a melhoria na aptidão física e nas habilidades motoras de ambos os grupos foi analisada. Resultados: Houve diferenças estatísticas entre os dois grupos de jovens atletas em diversos indicadores técnicos e de aptidão física. Conclusão: A força do core pode trazer melhorias às habilidades básicas de jovens atletas, tais como corrida em velocidade, saltos, e outras, mas seu efeito na melhoria da aptidão física de alto nível não é óbvio. O experimento mostrou que um certo perío do de treino de força do core pode aprimorar habilidades motoras e físicas. Recomenda-se a indicação do treino de força do core em treinamentos futuros para jovens. Nível de evidência ll; Estudos terapêuticos - investigação de resultados de tratamento.

Descritores: Adolescente; Atletas; Teste de Esforço; Treinamento de Força.

\section{RESUMEN}

Introducción: Un core más fuerte puedeser más establey auxiliar en la mejoría de la postura corporal de adolescentes. Esto permite que haya una integración orgánica y un desarrollo de todas las partes del cuerpo, así como la coordinación de los miembros superiores einferiores. El entrenamiento de la fuerza del core proporciona la mejoría de su fuerza fisica en el grupo dejóvenes. Objetivo: Estudiar la influencia de la fuerza del coreen las habilidades motoras y en la alfabetización física. Métodos: Fueron seleccionados 40 adolescentes para entrenamiento en grupo. El grupo experimental pasó por un entrenamiento de la fuerza del core, mientras que el grupo control pasó por entrenamientos de fuerza estándar. Después del periodo de entrenamiento, fue analizada la mejoría en la aptitud física y en las habilidades motoras de ambos grupos. Resultados: Hubo diferencias estadísticas entre los dos grupos de jóvenes atletas en diversos indicadores técnicos y de aptitud física. Conclusión: La fuerza del core puede proporcionar mejorías en las habilidades básicas de jóvenes atletas, tales como corrida en velocidad, saltos y otras, sin embargo, su efecto en el perfeccionamiento de la aptitud física de alto nivel no es obvio. El experimento mostró que un cierto periodo de entrenamiento de fuerza del core puede mejorar habilidades motoras y físicas. Se recomienda la indicación de entren amiento de fuerza del coreen preparaciones futuras para jóvenes. Nivel de evidencia Il; Estudios terapéuticos - investigación de resultados de tratamiento.

Descriptores: Adolescente; Atletas; Prueba de esfuerzo; Entrenamiento de fuerza. 


\section{INTRODUCTION}

Core strength training improves the coordination and flexibility of athletes by mobilizing coordinated movements of the whole body. In the process of core strength training, it can improve the speed, coordination and other sports literacy abilities. This ensures that the core muscles of young athletes remain stable and show higher stability during exercise. ${ }^{1}$ At present, the teaching theories, methods and methods adopted by most young athletes in the process of sports training are relatively traditional. Poor physical fitness and inadequate basic skills of young athletes have become the main factors affecting the effect of their physical exercises. This article uses core strength training theory to compare the effects of traditional strength training and core strength training on the physical fitness and basic skills of young athletes. In this way, we can explore the training model of the core strength of the youth group's physical strength and improve the corresponding training system process.

\section{METHOD}

\section{Research object}

We selected 40 young athletes and randomly grouped them. There are 20 people in the control group and 20 people in the experimental group. ${ }^{2}$ All athletes and their guardians have fully informed consent to the procedure and purpose of this experiment.

\section{Research methods}

In this study, the young athletes in the experimental group received core strength training, and the young athletes in the control group received traditional strength training. ${ }^{3}$ The adolescents in the experimental group and the control group had 12 weeks of strength training. Finally, compare the physical fitness and basic technical indicators of the experimental group and the control group before and after the experiment.

Core strength training mainly includes freehand training and equipment training. (1) Free-hand training: knee flexion cross, side arm flexion hip flexion knee flexion, double-end supine, side bend supine, prone two-point support, side-lying leg bending, etc. (2) Equipment training: lying on both ends of the ball, side-lying elbow support, holding dumbbells, flat lifting, arm support, bending leg to catch the Swiss ball, etc. The training is from shallow to deep, from easy to difficult, and is carried out in groups. The athletes receive 12 weeks of training.

The content of traditional strength training mainly includes (1) push-ups, push-ups, leg lifts, and push-ups at both ends. (2) Sit-ups, prone and leg lift, supine at both ends. (3) Barbell bench press, barbell deadlift, front neck lift, back neck lift, barbell squat, barbell squat. (4) Pull-ups and so on. Work in groups and train reasonably. The athletes receive 12 weeks of training.

\section{Modeling the Coordination Ability of Young Athletes' Upper and Lower Limbs}

This paper proposes a core force dynamics analysis model based on the Lagrangian dynamics model. ${ }^{4}$ The article uses the inverse kinematics analysis model to decompose the force of the whole joint structure of the core force action.

The Lagrangian dynamic model based on grid decomposition uses the redundancy of the athlete's right arm core strength to perform continuous mechanical decomposition actions. ${ }^{5}$

$$
C_{i j k l}=2 \frac{1}{4 V} \frac{\left(W^{*} \overline{\varepsilon_{i j} \overline{\varepsilon_{k l}}}\right)-W^{*} \overline{\varepsilon_{i j}}-W^{*} \overline{\varepsilon_{k l}}}{\varepsilon_{i j} \varepsilon_{k l}}
$$

$$
C_{i j k l}=2 \frac{1}{2 V} \frac{\left(W^{*} \overline{\varepsilon_{i j} \overline{\varepsilon_{k l}}}\right)-W^{*} \overline{\varepsilon_{i j}}-W^{*} \overline{\varepsilon_{k l}}}{\varepsilon_{i j} \varepsilon_{k l}}
$$

The Jacobian matrix of core strength training for young athletes is $J(\theta) \in R^{6 \times 10}$. We get the energy equivalent relationship of the movement burst as

$$
\theta=J^{*} P_{e}+\left(I-J^{+} J\right) \xi
$$

\section{Statistical methods}

The article uses SPSS 20.0 software for statistical analysis. Quantitative data is expressed in form $\bar{x} \pm s$. Paired t-test was used to compare the means of paired design data. ${ }^{6}$ Two independent sample t-test was used to compare the means of independent sample data. Data that does not meet the t-test conditions are compared using the rank-sum test. $P<0.05$ indicates that the difference is statistically significant.

\section{RESULTS}

\section{Comparison of the basic data of the two groups of young athletes before the experiment}

Before the experiment, the basic data of the experimental group and the control group young athletes were collected and sorted out. This provides a basis for future analysis of experimental results. ${ }^{7}$ The results in Table 1 showed that there was no statistically significant difference between the experimental group and the control group in terms of age, height, weight, approach height, and core strength training ( $P>0.05)$. This shows that there is no statistical difference between the basic data of the experimental group and the control group before starting the experiment.

\section{This article studies the influence of core strength on ado- lescents' motor skills and physical literacy}

Comparison of the physical stamina and basic skills of the two groups of young athletes before and after the experiment

By comparing the indicators of the two groups of young athletes before and after the experiment, the following results are obtained. Except for approach and exercise intensity, the differences in physical fitness of the young athletes in the experimental group before and after the experiment were statistically significant $(P<0.05)$. After the experiment, the rapid growth of core strength of young athletes was higher than before. ${ }^{8}$ There was no difference in various indexes of young athletes before and after the experiment. (Table 2) This shows that core strength training can improve the basic physical fitness of young people, such as fast running, jumping, etc., but the effect of technical training is not obvious.

Table 1. Comparison of the basic data of the two groups of young athletes before the experiment.

\begin{tabular}{c|c|c|c|c}
\hline & $\begin{array}{c}\text { Experimental } \\
\text { group }\end{array}$ & $\begin{array}{c}\text { Control } \\
\text { group }\end{array}$ & $\mathbf{t}$ & $\mathbf{P}$ \\
\hline Age & $19.6 \pm 1.37$ & $19.1 \pm 1.04$ & 1.3 & 0.201 \\
\hline Height $(\mathrm{cm})$ & $176.8 \pm 2.68$ & $177.6 \pm 2.56$ & 0.965 & 0.34 \\
\hline Weight $(\mathrm{kg})$ & $71.3 \pm 3.66$ & $71.8 \pm 3.23$ & 0.458 & 0.65 \\
\hline Approach height $(\mathrm{m})$ & $2.82 \pm 1.32$ & $2.84 \pm 1.88$ & 0.039 & 0.969 \\
\hline Fast running across the court & $36.8 \pm 1.14$ & $37.2 \pm 1.81$ & 0.836 & 0.408 \\
\hline Exercise frequency (times/minute) & $6.7 \pm 1.33$ & $7.2 \pm 1.34$ & 1.184 & 0.244 \\
\hline
\end{tabular}


Comparison of the physical stamina and basic skills of the two groups of young athletes after the experiment

There was a statistically significant difference in core strength development between the experimental group of young athletes and the control group of young athletes in the process of fast exercise $(P<0.05)$. The jumping height and distance of adolescent athletes in the experimental group were higher than those of the control group. ${ }^{9}$ This shows that core strength training can improve the basic skills of young athletes, such as fast running, jumping, etc., but the effect of improving high physical fitness is not obvious. (Table 3)

\section{DISCUSSION}

Improving the core strength of young people is a comprehensive sport. This sport has many requirements for physical fitness. The content includes body flexibility, flexibility and explosive power. Traditional sports training has been difficult to meet the new requirements of the development of modern science and technology on the physical fitness and basic athletic ability of college students, especially basic physical training. ${ }^{10}$ Core strength training is more scientific, diverse and innovative than traditional training methods.

Table 2. Comparison of physical stamina and basic skills of the two groups of young athletes before and after the experiment.

\begin{tabular}{c|c|c|c|c|c}
\hline & $\begin{array}{c}\text { Before the } \\
\text { experiment }\end{array}$ & $\begin{array}{c}\text { After the } \\
\text { experiment }\end{array}$ & Difference & $\mathbf{t}$ & $\mathbf{P}$ \\
\hline test group & & & & & \\
\hline Approach height (m) & $2.88 \pm 1.32$ & $2.95 \pm 1.21$ & $0.08 \pm 1.27$ & 0.282 & 0.781 \\
\hline $\begin{array}{c}\text { Rapid movement of } \\
\text { the whole field (s) }\end{array}$ & $36.8 \pm 1.14$ & $35.4 \pm 1.57$ & $1.44 \pm 1.33$ & 2.764 & 0.012 \\
\hline $\begin{array}{c}\text { Number of beats } \\
\text { (times/min) }\end{array}$ & $6.7 \pm 1.33$ & $8.9 \pm 1.08$ & $2.23 \pm 1.16$ & 8.597 & $<0.001$ \\
\hline $\begin{array}{c}\text { Comparison group } \\
\text { Jump height (m) }\end{array}$ & $2.84 \pm 1.88$ & $2.90 \pm 1.75$ & $0.05 \pm 1.77$ & 0.126 & 0.901 \\
\hline $\begin{array}{c}\text { The number of fast } \\
\text { dribbling runs (s) }\end{array}$ & $37.2 \pm 1.81$ & $36.6 \pm 1.64$ & $0.63 \pm 1.67$ & 1.055 & 0.305 \\
\hline $\begin{array}{c}\text { Exercise frequency } \\
\text { (times/min) }\end{array}$ & $7.2 \pm 1.34$ & $7.5 \pm 1.03$ & $0.34 \pm 1.31$ & 1.161 & 0.26 \\
\hline
\end{tabular}

Table 3. Comparison of physical stamina and basic skills of the two groups of young athletes after the experiment.

\begin{tabular}{c|c|c|c|c}
\hline & $\begin{array}{c}\text { Experimental } \\
\text { group }\end{array}$ & Control group & $\mathbf{t}$ & $\mathbf{P}$ \\
\hline Approach height $(\mathrm{m})$ & $2.95 \pm 1.21$ & $2.90 \pm 1.75$ & 0.105 & 0.917 \\
\hline $\begin{array}{c}\text { Rapid movement of } \\
\text { the whole court(s) }\end{array}$ & $35.4 \pm 1.57$ & $36.6 \pm 1.64$ & 2.364 & 0.023 \\
\hline Bounce frequency (times/min) & $8.9 \pm 1.08$ & $7.5 \pm 1.03$ & 4.195 & $<0.001$ \\
\hline
\end{tabular}

Relevant studies have shown that core strength training can improve the coordination, balance, flexibility and other physical qualities of young athletes, and improve the technical level and physical fitness of athletes. However, the traditional training method has a wide range of training and is not sufficient for physical training. ${ }^{11}$ It is impossible to conduct targeted training on the physical fitness and basic skills of young athletes, and the improvement effect is slow. This study confirmed that core strength training is a supplement to the physical and basic skills training of young athletes. This method can make up for the single training effect of traditional training methods and improve the overall quality of athletes' physical coordination and flexibility. Foreign scholars engaged in related research pointed out that core strength training has a limited effect on the improvement of certain physical fitness of young athletes in the short term. Only after a certain training time can the physical fitness index be improved, and the longer the training time, the more obvious the training effect. ${ }^{12}$ This study shows that core strength training failed to increase the height of entry of young athletes. This shows that it is difficult for core strength to improve physical fitness in a short period of time.

This study also has certain shortcomings. First of all, the main reason why we choose forty teenage athletes as the research objects is for the convenience of the study. ${ }^{13}$ However, due to individual differences in athletes, regional differences and other reasons, this study may have selection bias. Secondly, although this study carried out strict quality control on training methods and time, there are still many uncertain factors. For example, the lifestyle and physical condition of the athletes on the day of the test may cause errors in the test results and actual conditions.

\section{CONCLUSION}

Core strength training can improve the basic skills of young athletes, such as fast running, jumping and so on, but the effect of improving high physical fitness is not obvious.It can be seen that the introduction of core strength training into the daily strength training of young athletes can help improve the effects of long-distance running and jumping training for young athletes. Core sports can improve the physical quality and basic motor skills of young athletes.

\section{ACKNOWLEDGMENT}

Research Project of Guangxi Philosophy and Social Science Planning: Research on the Design and Practice of Functional Fitness Training for Guangxi Adolescents (Approval number: 20FTY013)

All authors declare no potential conflict of interest related to this article

AUTHORS' CONTRIBUTIONS: Each author made significant individual contributions to this manuscript. Juqian Pan: writing and performing surgeries; Meiliang Wei: data analysis and performing surgeries, article review and intellectual concept of the article.

\section{REFERENCES}

1. Soslu R, Özer Ö, Güler M, Doğan AA. Is there any Effect of Core Exercises on Anaerobic Capacity in Female Basketball Players?. Journal of Education and Training Studies. 2019;7(3):99-105.

2. Liu J.The Development and Promotion of Three-Man Basketball in Ordinary Colleges and Universities Based on the Background of National Fitness. Academic Journal of Humanities \& Social Sciences. 2019;2(2):93-7.

3. Nuhmani S. The FIFA $11+$ does not alter performance in amateur female basketball players - a randomized control trial. Journal of Complementary and Integrative Medicine. 2021;18(2):379-83.

4. Andrews D, Banks C. An Assessment of the Benefits of Off-Season Training Among Teenage Basketball Players. Physical Educator. 2020;77(5):801-12.

5. Elkeky AA, Esmail M, Alkhaldy F. The Effect of Using Cross Training on Improving Some of the Physical abilities of Basketball players and its Relationship to the Biochemical Variables. Journal of Applied Sports Science. 2020;10(1):120-33.

6. Genc $H$, Cigerci AE, Sever O. Effect of 8-week core training exercises on physical and physiological parameters of female handball players. Physical education of students. 2019;23(6):297-305.

7. Freitas TT, Calleja-González J, Carlos-Vivas J, Marín-Cascales E, Alcaraz PE. Short-term optimal load training vs a modified complex training in semi-professional basketball players. Journal of sports sciences. 2019;37(4):434-42
8. Zhang S, Lorenzo A, Zhou C, Cui Y, Gonçalves B, Angel Gómez M. Performance profiles and opposition interaction during game-play in elite basketball: evidences from National Basketball Association. International Journal of Performance Analysis in Sport. 2019;19(1):28-48.

9. Mankar SS. A comparative study of effect of sand and land plyometric training on speed and explosive power among basketball players. Journal of Sports Science and Nutrition. 2020;1(2):37-9.

10. Han C. Urban air pollution resolution and basketball training optimization based on time convolution network. Arabian Journal of Geosciences. 2021;14(18):1-7.

11. Usgu S, Yakut Y, Kudaş S. Effects of Functional Training on Performance in Professional Basketball Players, Spor Hekimliği Dergisi. 2020;55(4):321-31.

12. Plummer HA, Wilkerson GB, Bruce JR, Lamour RJ, Ostrander III RV. Preliminary Findings of Lower Extremity Injury Risk Categorization Through Lumbopelvic-Hip Endurance Screening of High School Basketball Players. Athletic Training \& Sports Health Care. 2020;12(3):127-34.

13. Firouzjah EMAN, Daneshmandi H, Norasteh AA. Effect of Core Stability Training on the Endurance and Strength of Core in Basketball Players with Trunk Dysfunction. Journal of Rehabilitation Sciences \& Research. 2020;7(2):80-6. 